\title{
The contractual relationships in the Italian durum wheat chain: empirical survey evidence
}

\author{
Roberto Solazzo*, Gaetana Petriccione*, Maria Angela Perito**
}

DOI: $10.30682 / \mathrm{nm} 2002 \mathrm{~g}$

JEL codes: D22, P32, Q18

\begin{abstract}
The paper investigates the vertical relations along the Italian durum wheat chain and the factors affecting farmers' behavior in adopting contractual agreements. Sale/crop-growing contracts in the durum wheat sector are analyzed through a direct survey to a sample of 261 durum wheat farmers. The questionnaire collected data on downstream relations and contract terms between farmers and processing and/or marketing firms along the durum wheat chain. A logit model is used to identify factors affecting the likelihood of contract farming between farms and processors. One of the main issues emerging is the low frequency of written contractual forms between durum wheat farmers and downstream operators. In most cases the farmers do not want constraints and reveal a lack of trust in contracts. They prefer to sell their product to a local downstream operator with whom they have a long-standing and solid relationship of trust. Moreover, results of a logistic model show that certain farm features, such as turnover and degree of specialization in durum wheat production, play an important role in driving the decision to adopt written contracts.
\end{abstract}

Keywords: Contractual relationships, Farmers'behavior, Supply chain, Logit model, Durum wheat.

\section{Introduction}

Modern market channels demand greater coordination along the supply chain and specific contracts between the agricultural producers and downstream operators (Worley and McCluskey, 2000; Reardon, Gulati, 2008; Fernández-Olmos and Vinuesa, 2009; Jang and Olson, 2010; Malorgio et al., 2016; Xhoxhi et al., 2019).

The way in which governance mechanisms are developed in the agrifood system is a relevant field of research. In his seminal work, Stoker (1998) defines governance as a "set of institutions and actors that are drawn from but also beyond government, aiming at identifying boundaries and responsibilities for tackling social and eco- nomic issues" (p. 18), bringing about something without the need for government authority.

In this light, a contract can be considered a tool for helping smallholder farmers to access more remunerative markets, to provide inputs and credit and reduced price risks (Key and McBride, 2003; Da Silva and Rankin, 2013; Nguyen et al., 2015; Otsuka et al., 2016; Nait Mohand et al., 2017).

As Menard (2008) points out, "contract represent a focal point in relaxing the constraints of bounded rationality, fixing schemes of references for future actions, and checking on opportunistic behaviour" (p. 282).

Some authors (Key and Runsten, 1999; Katchova and Miranda, 2004) have highlighted how a contract represents an institutional solution to problems of market failures. In particular, this

\footnotetext{
* CREA - Research Centre for Agricultural Policies and Bioeconomy, Rome, Italy.

** University of Teramo, Teramo, Italy; Université Paris-Saclay, INRA, UR ALISS, Ivry-sur-Seine, France.

Corresponding author: roberto.solazzo@crea.gov.it
} 
form of relationship governance solves a number of productivity constrains for small farmers including reduced market risks, access to credit, inputs and information (Xhoxhi et al., 2019).

Worley and McCluskey (2000) identify three main classes of contracts, according to increasing degrees of control by the contractor: marketing contracts, production management contracts, and production contracts with specified resources provided. Marketing contracts set a price or a pricing mechanism, a delivery outlet, and a quantity to be delivered before harvest. They often provide premiums for meeting quality targets. Furthermore, they usually specify penalties for particular kinds of non-fulfilment. This kind of contract is commonly used in the cereal chain relations. Within marketing contracts, forward contracts have been developed. The latter establish a base price and a given quantity to be delivered within a specified time. Forward contracts are usually linked to the concepts of the uncertainty related to price risk management, and income stabilisation (Barnard and Nix, 1980; Fraser, 1997; Jackson et al., 2008; Wilson and Dahl, 2011; Roussy et al., 2017).

As regards production contracts with specified resources provided, the provision also concerns input and technical support by the contractor. In this type of contract, farmers are paid for the services they provide. In the durum wheat chain the Italian pasta companies promote production contracts to ensure the provision of national or local durum wheat with specific quality characteristics. This because the quality of pasta strictly depends on the characteristics of the durum wheat utilized. For this purpose, these contracts agree upon specific premiums to improve durum wheat quality in terms of protein content. Moreover, the use of production contracts allows processors to manage the risks involved in the high quality durum wheat supply chain (Ferrari, 2014).

Reardon et al. (2009), in an empirical work in developing countries, showed that incomes of smallholders who produce under contract are larger than incomes of those who do not. Numerous studies, reviewed in Ton et al. (2018), confirm the positive correlation between farm earnings and contractual agreements. Though positive effects may derive from contractual agreements, the majority of Italian durum wheat is sold on spot markets, mainly because of the small size of the farms (Carillo, 2016).

Moreover, as pointed out by Drescher and Maurer (1999), the fear of losing autonomy and of being at the mercy of one market partner hinders the establishment of contracts. Farmers' trust on downstream buyer appears to be a strong predictor of farmers' decision to enter in a contractual agreement (Morgan and Hunt, 1994). Trust is viewed as an important element for sustainable relationships (Macneil, 1980). Reputation of downstream buyer can be an added incentive mechanism to induce performance under a contract (King, Backus and Gaag, 2007).

The existence of asymmetric information could also play a role in the effectiveness of contractual relationships (Fernández-Olmos et al., 2011; Bouamra-Mechemache et al., 2015).

The issue of contracting and vertical integration in the wheat chain has acquired a great significance in the literature (Duval and Biere, 1998; Worley and McCluskey, 2000; Wilson et al., 2004; Bolotova and Patterson, 2008; Viaggi and Zanni, 2012; Carillo, 2016). Many governments and donors promote contract farming as part of agricultural development policies. Contracts and vertical coordination between actors within food supply chain, as well as producer and interbranch organisation instruments, are key issue for European Commission policies. In particular, written contracts have been recognised as an instrument to improve coordination along the food supply chain (Milk Package, the 2013 CAP reform and proposals on post 2020). Contracts can also be used to ensure that farmers produce high-quality products and to avoid risks of bargaining power along the supply chain (Worley and McCluskey, 2000; Perito et al., 2017; Bonanno, Russo and Menapace, 2018). Nevertheless, farmers have to face a quantity-quality trade-off in relation to the received price. This raises the issue of the optimal choice in terms of efficiency and competitiveness of governance mechanisms in the contractual relationships (Fernández-Olmos and Vinuesa, 2009). In this regard policy makers should encourage more efficiently vertical coordination by "leveraging vertical contract through policy mechanisms for growers' benefit" (Benmehaia and Brabez, 2018, p. 13). 
Despite the rich academic literature, few empirical works have looked at the role of different contractual agreements in the durum wheat sector. We try to fill this gap by investigating factors which drive the choice of whether to adopt a specific contract agreement in the Italian durum wheat sector. We also investigate the main problems in the organizational structure of the durum wheat chain in Italy and highlight key aspects useful to policymakers for improving the effectiveness and the spread of contractual instruments. The results of a direct survey and a logistic regression model allow us to highlight obstacles and benefits of using contract farming. The study is organised in three sections: sampling procedure and methodological approach, results and discussion, and final remarks on the empirical results.

\section{Materials and methods}

The main problem of the empirical analysis on contracts concerns the difficulty of access to contract information. Many empirical studies investigating contracts in agri-food supply chains have employed direct survey procedure, often associated with other methodologies (among others, Fischer et al., 2009; Vavra, 2009; Franken et al., 2012; Viaggi and Zanni, 2012; Carillo, 2016; Roussy et al., 2017).
We approached the empirical analysis of the contractual agreements in the Italian durum wheat chain using a two-step method.

First, a direct survey was carried out to collect information on the supply chain organization and the use of contractual agreements at farm level in the period 2015-2016. In particular, we asked farmers how they regulated their production and sale of durum wheat, and why they chose to sign or not sign a written contract.

For this purpose, a questionnaire ${ }^{1}$ was submitted to a sample of 300 durum wheat farms belonging to the Italian Farm Accountancy Data Network (FADN) database. ${ }^{2}$ Seven Italian regions were selected for distribution of the questionnaire: Emilia-Romagna, Abruzzi, Marche, Campania, Tuscany, Apulia and Sicily. ${ }^{3}$ The sample accounted for about $25 \%$ of the FADN durum wheat population in these regions.

The farms were selected taking into account the province where they were located, the degree of specialization in durum wheat growing and size classes of durum wheat hectares.

The sample included farms above two hectares, highly differentiated by size and production specialization. The farm size under durum wheat varied from just over one hectare to more than 500 hectares (Table 1).

Table 1 - Percentage distribution of the sample by region and area under durum wheat.

\begin{tabular}{|c|c|c|c|c|c|c|c|c|}
\hline $\begin{array}{c}\text { Size classes } \\
\text { (ha of durum wheat) }\end{array}$ & Abruzzi & Campania & Emilia-R. & Marche & Apulia & Sicily & Tuscany & Total \\
\hline$<2$ & 0.4 & 1.1 & 2.7 & 0.0 & 0.8 & 0.8 & 0.4 & 6.1 \\
$2-5$ & 0.8 & 1.9 & 3.8 & 1.5 & 2.3 & 4.2 & 0.4 & 14.9 \\
$5-10$ & 2.3 & 3.4 & 4.2 & 1.1 & 4.2 & 3.8 & 2.7 & 21.8 \\
$10-30$ & 1.9 & 3.1 & 6.1 & 1.9 & 8.4 & 6.9 & 5.4 & 33.7 \\
$30-100$ & 1.9 & 0.8 & 3.1 & 3.4 & 6.5 & 2.7 & 2.7 & 21.1 \\
$>100$ & 0.0 & 0.0 & 0.0 & 0.8 & 0.8 & 0.0 & 0.8 & 2.3 \\
\hline Total & 7.3 & 10.3 & 19.9 & 8.8 & 23.0 & 18.4 & 12.3 & 100 \\
\hline
\end{tabular}

Source: our survey data processing.

\footnotetext{
1 The questionnaire was previously tested by experts and key actors in the Italian durum wheat supply chain.

2 The FADN sample covers $95 \%$ of the total used agricultural area on average at national level.

3 The selection criterion was based on the significance of these regions for the national durum wheat production. In 2016 the total durum wheat area in Italy reached about 1.38 million hectares, which corresponded to production of 5.0 million tons. The seven regions selected account for more than $75 \%$ of that production.
} 
Thirty-nine companies out of 300 did not respond to answer the questionnaire and the final panel size was 261 respondents.

Data on contracts were collected by professional subjects in face-to-face interviews with farmers using a questionnaire, which was organized in four sections: i) General information about socio-demographic characteristics (age, education) and farm characteristics (total hectares in production, total hectares in durum wheat, product quantity, etc.). ii) Their forms of horizontal and vertical organization along the supply chain. iii) Relevant contractual aspects about the product selling (price, premium price for quality, minimum quantity and cultivar, etc.). Moreover, respondents were asked which downstream subjects they signed written contracts with. Another question, among others, concerned the type on contract: spot or forward. iv) Satisfaction/ dissatisfaction elements regarding contractual relationships with downstream operators. We also gathered qualitative information in order to understand which reasons behind farmers' choices to sign or not a written contract. Where a written contract was in use, we asked respondents to indicate improvements in terms of income growth, market opportunities, product price, product quality and/or decrease in terms of price volatility and sales risk. Where no contract was in force, we asked respondents the reasons for this choice.

The survey used five-point Likert-scales to measure the attitude of the durum wheat farmers interviewed.

The information obtained was used to develop a logistic regression model in order to describe whether and to what extent characteristics of farms, identified by the survey, affect their choice of adopting or not a written contract for durum wheat sale. The majority of studies analyzing contractual agreements use a combination of survey (interview) methods, contract analysis, and simulation techniques (Bolotova and Patterson, 2008; Johnson and Foster, 1994; Parcell and Langemeier, 1997; Lajili et al., 1997; Gillespie and Eidman, 1998), and then either econometric or statistical techniques to test the hypotheses.
In our research we opted to use a logistic regression model because it meets appropriately our research requirements. Our choice is supported by the widespread use of this methodology to investigate issues related to the contract farming determinants (Arumugam et al., 2011; Opoku - Mensah, 2012; Swain, 2012; Kumar et al., 2010).

Logistic regression allows the linear modeling of nonlinear relations between a dichotomous dependent variable, and one or more independent variables, using a logarithmic transformation. In the model, the dependent variable $\mathrm{Y}$ is distributed as a Bernoulli random variable and expresses the probability that $\mathrm{Y}$ takes a certain value, given the value $(\mathrm{x})$ assumed by the independent variables $\left(\mathrm{X}_{1}, \mathrm{X}_{2}, \ldots, \mathrm{X}_{\mathrm{k}}\right)=\mathrm{X}$.

The relationship between $\mathrm{Y}$ and $\mathrm{X}$, function $\pi$ (x), can be represented by a logistic distribution and the model has the following form:

$$
\operatorname{logit}[\pi(\mathrm{x})]=\ln \frac{\pi(\mathrm{x})}{1-\pi(\mathrm{x})}=\beta_{0}+\beta_{1} \mathrm{x}_{1}+\beta_{2} \mathrm{x}_{2}+\ldots+\beta_{\mathrm{k}} \mathrm{x}_{\mathrm{k}}
$$

where the odds ratio $(\operatorname{Exp}(\beta))$ shows to what extent one unit change in the independent variable increases the ratio of probability $(\pi(\mathrm{x}))$ that the dependent variable takes value 1 (use of written contracts) versus the probability $(1-\pi(\mathrm{x}))$ that it takes value 0 (no use of written contracts).

Based on this conceptual framework, the predictors assumed to have an impact on propensity to sign a contract suggest seven hypotheses linked to farmers and farm characteristics (Table 2).

The age of farmer may be important in explaining the likelihood of a "written contract" being chosen by farmers to regulate the sale (or crop-growing) of durum wheat, so we classified farmers as "under/over 60 years old". We also considered educational qualifications as an independent variable, assuming that a higher qualification would increase the likelihood of using a written contract.

As regards physical farm characteristics, the model includes turnover, the area of durum wheat and the specialization level, assuming that the larger and more specialized farms are more likely to regulate sales through written contracts.

Other farm characteristics considered in the model are type of management, i.e. whether they 
Table 2 - Independent variables used in the logistic regression model.

\begin{tabular}{|l|l|l|l|}
\hline Types of hypothesis & Independent variables & \multicolumn{1}{|c|}{ Description } & \multicolumn{1}{|c|}{ Classes and scores (1/0) } \\
\hline \multirow{5}{*}{$\begin{array}{l}\text { Farmer } \\
\text { characteristics }\end{array}$} & Age & Age of farmer & Over/under 60 years \\
\cline { 2 - 4 } & Qualification & $\begin{array}{l}\text { Educational qualification of } \\
\text { farmer }\end{array}$ & $\begin{array}{l}\text { Graduated/ } \\
\text { not graduated }\end{array}$ \\
\hline \multirow{5}{*}{$\begin{array}{l}\text { Farm } \\
\text { characteristics }\end{array}$} & Turnover & $\begin{array}{l}\text { Turnover (standard output) } \\
\text { of farm }\end{array}$ & $\begin{array}{l}\text { More/less than } \\
€ \text { 500,000 }\end{array}$ \\
\cline { 2 - 4 } & Durum wheat area & $\begin{array}{l}\text { Area of durum wheat } \\
\text { growing }\end{array}$ & Hectares of durum wheat \\
\cline { 2 - 5 } & Specialisation & $\begin{array}{l}\text { Specialisation of farm in } \\
\text { durum wheat growing }\end{array}$ & $\begin{array}{l}\text { Share of area with durum } \\
\text { wheat }\end{array}$ \\
\cline { 2 - 5 } & Management & Type of farm management & Direct family run / others \\
\cline { 2 - 4 } & Innovation & $\begin{array}{l}\text { Innovations introduced } \\
\text { into production and/or } \\
\text { management in the last } 5 \\
\text { years }\end{array}$ & $\begin{array}{l}\text { Innovations/ } \\
\text { no innovations }\end{array}$ \\
\hline
\end{tabular}

Source: our survey data processing.

are directly family run or other, ${ }^{4}$ and propensity to innovation. Innovation propensity is a dichotomous variable and distinguishes whether the farm has applied or not production/management innovations in the last 5 years. We hypothesized a link between higher propensity to innovate and the adoption of written contractual forms.

\section{Results}

As regards the direct survey, more than half of the respondents were aged between 40 and 60 . Within this age band, middle and high school qualifications prevailed. On the other hand, as expected, farmers aged over 60 (more than 38\%) mainly had primary and middle school education levels. It is interesting to note that farmers under 40 years old accounted for only 10 percent of the total, and all held middle and high school qualifications.

The first result of the survey was that only 31 of 261 farms analyzed (about 12\%) signed a contract for the production/marketing of durum wheat. Most of these contracts (84\%) were forward. Among the seven regions, only Emilia-Romagna showed a higher rate, with $31 \%$ of respondents usually signing written contracts. In fact, half of the written contracts revealed by the survey were from this region. The main reason is that the leading company on the world pasta market, which developed the "Accordo Quadro nel Settore del Grano Duro di Alta Qualità", a framework contract sponsored by the regional institution, is in this region (Ferrari, 2014). Furthermore, a long-standing tradition and culture in co-operation facilitated the use of coordinating tools among the actors along the chain in this area. In fact, most of the written contracts for durum wheat in Emilia-Romagna were signed by farmers with agricultural consortia, which are a well-established and widespread tool for selling commodities (cereals) as well as purchasing input. Finally, the institutional environment also seemed to play a role in promoting and supporting collective actions between producers.

The results show that almost all the surveyed farms with written contracts recognized the positive aspects, and only one declared no benefits in terms of certainty of income, cost reduction or quality improvement. For the other 30 farms, signing a written contract represented an added value in relation to one or more aspects.

\footnotetext{
${ }^{4}$ In the questionnaire the types of management other than family run are: management with prevalence of family members, management with prevalence of non-family members, management with employee, management with only subcontracting, other types of management.
} 
Almost two-thirds of respondents stated that the main benefit of written contracts was the guarantee of a more secure and stable income, as shown by Figure 1 . For more than $43 \%$ of the farmers, another important benefit was the certainty of a market outlet. Reduction of uncertainty in terms of market and income, and lowering the risks associated with them, was recognized by farmers as the most important benefit of contractual arrangements (Viaggi and Zanni, 2012).

There was also a significant increase in farm income. For more than $20 \%$ of farmers it derived from a reduction in storage costs or selling at a price higher than the market price. Signed contracts appeared to have less effect on the improvement in yield, product quality or cultivation techniques.

Another interesting issue emerging from the questionnaire was farmer ability to adopt innovation and developing new methods of organization and management, as well as changing their relationships with other subjects including private and public institutions. Farms with written contracts were more dynamic than the others, highlighting a greater innovation development capacity, probably stimulated by contractual conditions on raw material quality, technical practices, etc. This is a significant finding because it appears that farmers relate to technical and/or organizational innovation in a different, more receptive manner through contractual ar- rangements. This could translate into along run improvement in economic performance.

With regard to farms which did not sign written contracts but regulated their durum wheat sales by verbal agreements $(88 \%)$, the survey highlighted that farmers had consolidated relations with buyers, or "longstanding relationships", mainly based on trust. In many cases the trust in established relationships significantly influenced the decision to make verbal agreements rather than written contracts.

In order to find out why these farmers did not choose written contracts for production/marketing of durum wheat, we investigated the factors affecting the non-use of written contracts, and asked farmers about the main reason for this choice.

First, for almost half of the farms the main problem lies in the constraints laid down in a contract (Table 3). Farmers did not want constraints, because these limit their decision-making autonomy in the cultivation and sale of durum wheat. Contracts in fact often specify cultivation practices in order to make the production process more efficient and uniform. In the most binding contracts, farmers become providers of land, resources, and management services for a fee. The problem is the trade-off between risk and independence, on one side, and income stability, on the other. It is clear that farmers should be able to take decisions in their own best interests (Worley and McClus-

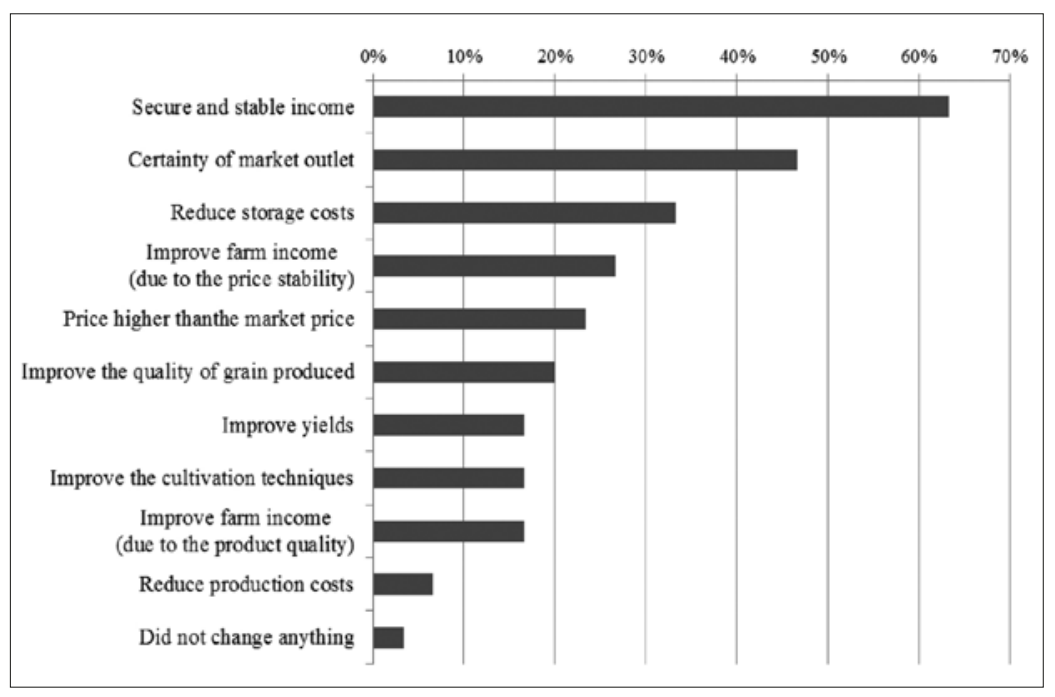

Figure 1 - Benefits of choosing written contracts for cultivation/sale experienced by farmers. Source: our survey data processing. 
Table 3 - Reasons for non-use of a written contract ( $\%$ distribution by age group).

\begin{tabular}{|l|c|c|c|c|}
\hline \multirow{2}{*}{\multicolumn{1}{c|}{ Reason }} & \multicolumn{3}{c|}{ Age of the farmer } & \multirow{2}{*}{ Total } \\
\cline { 2 - 4 } & $\begin{array}{c}\text { Under } \\
\text { 40 years }\end{array}$ & $\begin{array}{c}\text { From 40 } \\
\text { to 60 years }\end{array}$ & $\begin{array}{c}\text { Over } \\
60 \text { years }\end{array}$ & 7.7 \\
\hline Lack of information & 13.0 & 6.3 & 8.0 & 48.9 \\
I do not want constraints & 39.1 & 50.5 & 49.4 & 13.6 \\
It is not economical & 13.0 & 14.4 & 12.6 & 5.0 \\
It is risky & 0.0 & 5.4 & 5.7 & 10.9 \\
I do not trust other parties & 17.4 & 7.2 & 13.8 & 14.0 \\
Other & 17.4 & 16.2 & 10.3 & 100 \\
\hline Total & 100 & 100 & 100 & \\
\hline
\end{tabular}

Source: our survey data processing.

key, 2000), but they often lack access to right information.

In fact, $7.7 \%$ of respondents state they lack information about contracts. Surprisingly farmers under 40 showed the highest percentage of lacking information (13\%), and the highest percentage of lacking trust $(17.4 \%)$. Younger farmers also showed higher percentages regarding constraints $(39.1 \%)$. In fact there was a serious and widespread problem of knowledge about contractual arrangements involving almost all respondents, including younger and graduate farmers.

The analysis by size classes also provides interesting results (Table 4). While for small farms under 10 hectares, the main obstacles to the signing of written contracts were the lack of information and trust together with the constraints, for big farms (over 100 hectares) the main reasons were the constraints - for almost two-thirds of this category of farms - and the risks they perceived in them. It is clear that, on the one hand, the "big" farmers wanted to preserve their decision-making autonomy, but on the other hand, more generally, there are clearly land and social structural problems in Italian agriculture together with an absence of an effective organization of the chain.

As regards the results of the logistic regression model, with which we investigated characteristics of the surveyed farms, four variables (innovation, economic size, management and specialization) are statistically significant (Table 5), two at the 0.01 level and two at 0.1 level, affecting positively the producers' likelihood of signing written contracts.

Table 4 - Reasons for non-use of a written contract (\% distribution by size classes).

\begin{tabular}{|l|c|c|c|c|c|c|}
\hline \multirow{2}{*}{\multicolumn{1}{|c|}{ Reason }} & \multicolumn{7}{c|}{ Total area (ha) } & \multirow{2}{*}{ Total } \\
\cline { 2 - 7 } & $<10$ & $10-30$ & $30-50$ & $50-100$ & $>100$ & \\
\hline Lack of information & 11.1 & 10.1 & 8.1 & 2.7 & 4.9 & 7.7 \\
I do not want constraints & 48.1 & 46.8 & 40.5 & 45.9 & 63.4 & 48.9 \\
It is not economical & 7.4 & 13.9 & 18.9 & 18.9 & 7.3 & 13.6 \\
It is risky & 3.7 & 3.8 & 2.7 & 5.4 & 9.8 & 5.0 \\
I do not trust other parties & 18.5 & 12.7 & 8.1 & 13.5 & 2.4 & 10.9 \\
Other & 11.1 & 12.7 & 21.6 & 13.5 & 12.2 & 14.0 \\
\hline Total & 100 & 100 & 100 & 100 & 100 & 100 \\
\hline
\end{tabular}

Source: our survey data processing. 
Table 5 - Logistic regression model results.

\begin{tabular}{|l|c|c|c|c|c|c|}
\hline \multicolumn{1}{|c|}{ Variables } & $B$ & S.E. & Wald & $d f$ & Sig. & $\operatorname{Exp}(B)$ \\
\hline Age & -.235 & .409 & .330 & 1 & .566 & .791 \\
Qualification & .661 & .689 & .921 & 1 & .337 & 1.937 \\
Innovation & 1.191 & .465 & 6.560 & 1 & .010 & $3.289^{* * *}$ \\
Economic size & .987 & .600 & 2.704 & 1 & .100 & $2.682^{*}$ \\
Management & -1.611 & .360 & 20.026 & 1 & .000 & $.200^{* * *}$ \\
Durum wheat area & -.017 & .011 & 2.545 & 1 & .111 & .983 \\
Specialisation & -.017 & .007 & 5.486 & 1 & .019 & $.983^{* *}$ \\
\hline Negelkerke $\mathrm{R}^{2} .678$ &
\end{tabular}

* Significant at the 1 level; ** Significant at the .05 level; *** Significant at the .01 level.

Source: our survey data processing.

Almost $88 \%$ of the cases are correctly classified by the model and a Nagelkerke R2 of 0.687 suggests a very good fit. ${ }^{5}$

As noted above, the odds ratio (Exp (B)) indicates the ratio of the conditional probability relationships. When it is greater than 1 , the variable affects the farmers' likelihood of entering into a contract positively, while when it is less than 1 the variable affects it negatively.

The variables with the highest odds ratio concern innovation introduced into production and/ or management in the last 5 years. Therefore, as we assumed, the relative propensity to sign a written contract is significantly higher for farms which showed a greater propensity to innovate. This was probably because farmers who are also innovators were more willing to "search out information on new opportunities" (Duval and Biere, 1998), and, thus, to take risks connected to the contractual instruments. High turnover, above 500,000 euro, and a higher degree of specialization in durum wheat production are also significant determinants of a greater propensity to written contracts. Being run by a family reduces the chance of a farm selling its durum wheat through written contracts. Our findings however are that the extension of the surface of durum wheat and the characteristics of farmers (age and educational qualifications) are statistically insignificant.

\section{Conclusion}

One of the main findings of our analysis was the low frequency of written contractual forms between durum wheat farmers and downstream operators. Only $12 \%$ of the sample used written contracts. In most cases, farmers did not want constraints and revealed a lack of trust in contracts. They preferred to sell their production to local buyers, usually private dealers, with whom they had established long-standing relationships.

We found a clear contrast between the majority of respondents who chose not to sign written contracts and improvements and advantages experienced by those producers who adopted these instruments. This may be explained by several factors shown in the survey results. First of all, long-term relationships between durum wheat producers and local buyers were one of the main reasons for not making written contracts. Relations were based on mutual trust and confidence, entailing detailed knowledge on prices, quality, deliveries, services, etc. (Johanson and Mattsson, 2015).

Secondly, autonomy in decision-making was another significant factor for farmers who did not want to be subject to contractual commitments. Underlying this, there was a significant lack of information on the possible benefits of written contracts. In this aspect, the institutional

\footnotetext{
5 Values of Nagelkerke $\mathrm{R}^{2}$ greater than 0.2 indicate acceptable performance, values greater than 0.4 good and values greater than 0.5 very good performance (Backhaus et al., 2006).
} 
environment and particularly local policy could play a significant role in stimulating and regulating the use of contracts, as well as disseminating knowledge of them (Vavra, 2009). The social environment, or what has been called "neighbour behaviour" (Donati et al., 2015; Casolani et al., 2019), could also influence farmers' behaviour in adopting contractual agreements.

As regards the results of the logistics model, we found that some farm features, such as turnover, the degree of specialisation in durum wheat production, as well as non-family management, played an important role in driving the decision to adopt written forms of contract. The propensity to innovate also affected positively the likelihood of the use of written contracts. More specifically, looking at the survey and logit model outcomes, there was a correlation between innovation propensity and the producers' willingness to sign contracts.

In this context, the Common Agricultural Policy 2014-2020, confirmed by the legislative proposals beyond 2020, give a boost to contractual instruments and chain organisations, key issues in rebalancing bargaining power in food chain. Improving the effectiveness and the coordination of the relations along the food supply chain is a concern of the European Commission policies, that have moved to overcome problems tied to contractual imbalance associated with unequal bargaining power. This issue needs to be tackled in a complex and coherent framework including all the various instruments, and all aspects of the organisation and regulation of market relations, which coexist and act in synergy (Giacomini, 2013; Zanni and Viaggi, 2012).

In this view, producer organisations and other forms of horizontal cooperation between farmers are instruments that may strengthen farmers' position in the food supply chain by ensuring, among others, greater bargaining power in the contractual negotiations with downstream operators. For the durum wheat chain their involvement in contractual relationships with processors is the way for farmers to get better conditions, as the experience of the aforementioned framework contract for high-quality durum wheat has demonstrated.

\section{References}

Arumugam N., Arshad F.M., Chiew E.F.C., Mohamed Z., 2011. Determinants of Fresh Fruits and Vegetables (FFV) Farmers' Participation in Contract Farming in Peninsular Malaysia. International Journal of Agricultural Management and Development (IJAMAD), 1(2): 1-7.

Backhaus K., Erichson B., Plinke W., Weiber R., 2006. Multivariate Analysemethoden. Eine anwendungsorientierte Einführung, 11. Auflage. Berlin, Heidelberg: Springer.

Barnard C.S., Nix J.S., 1980. Uncertainty and farm organization and planning. In: Farm Planning and Control, $2^{\text {nd }}$ ed. Cambridge: Cambridge University Press, pp. 382-411, doi:10.1017/ CBO9780511559914.020.

Benmehaia M.A., Brabez F., 2018. Vertical relationships and food supply chain coordination: The case of processing tomato sector in Algeria. New Medit, 17(2): 3-14.

Bolotova Y., Patterson P.E., 2008. Contractual Relations in Production and Marketing of Potatoes, Barley, and Wheat in Idaho: A Procedure for an Empirical Analysis. Journal of Food Distribution Research, 39(1): 25-30.

Bonanno A., Russo C., Menapace L., 2018. Market power and bargaining in agrifood markets: A review of emerging topics and tools. Agribusiness, 34(1): 6-23.

Bouamra-Mechemache Z., Duvailex-Tréguer S., Ridier A., 2015. Contrats et modes de coordination en agriculture. Economie Rurale, 345: 7-28.

Carillo F., 2016. Vertical integration in Italian pasta supply chain: A farm level analysis. Rivista di Economia Agraria, LXXI(1): 47-66.

Casolani N., Perito M.A., Liberatore L., 2019. The Role of Innovation Poles in Agri-Food System Development: The Case of Abruzzo's Model. International Journal on Food System Dynamics, 10(4): 315-331.

Da Silva C.A., Rankin M., 2013. Contract farming for inclusive market access. Rome: FAO.

Donati M., Menozzi D., Fioravanzi M., 2015. Understanding Farmers' Responses to CAP Reform. New Medit, 14(3): 29-39.

Drescher K., Maurer O., 1999. Motives, Consequences and Determinants of Vertical Contractual Relations in Agriculture: Some Results of an Empirical Investigation in Germany. In: Galizzi G., Venturini L. (eds), Vertical Relationships and Coordination in The Food System. Heidelberg: Physica-Verlag, pp. 251-266. 
Duval Y., Biere A., 1998. Grain producers' attitudes to new forms of supply chain coordination. International Food and Agribusiness Management Review, 1(2): 179-193.

Fernández-Olmos M., Grazia C., Perito M.A., 2011. Quality and double sided moral hazard in share contracts. Agricultural Economics Review, 12(1): 22-35.

Fernández-Olmos M., Vinuesa L.M.M., 2009. Spot Market versus Incentive Contract. New Medit, 8(3): 12-20.

Ferrari E., 2014. Creating Value in the Durum Wheat Supply Chain: the Barilla Experience in the Contract Farming in Italy. Economia agro-alimentare, 1: 179-188.

Fischer C., Hartmann M., Reynolds N., Leat P., Revoredo-Giha C., Henchion M., Albisu L.M., Gracia A., 2009. Factors influencing contractual choice and sustainable relationships in European agri-food supply chains. European Review of Agricultural Economics, 36(4): 541-569.

Franken J.R.V., Pennings J.M.E., Garcia P., 2012. Crop Production Contracts and Marketing Strategies: What Drives Their Use?. Agribusiness, 28(3): 324-340.

Fraser R., 1997. Seasonal variability, land values and willingness-to-pay for a forward wheat contract with protein premiums and discounts. The Australian Journal of Agriculture and Resource Economics, 41(2): 139-155.

Giacomini C., 2013. La politica della UE per l'aggregazione delle imprese agroalimentari. Agriregionieuropa, 9(35).

Gillespie J.M., Eidman V.R., 1998. The Effect of Risk and Autonomy on Independent Hog Producers' Contracting Decisions. Journal of Agricultural and Applied Economics, 30(1): 175-188.

Jackson E., Quaddus M., Islam N., Stanton J., 2008. A mixed-method approach for determining the risk and complexity farmers associate with using forward contracts. Presented at the $82^{\text {nd }}$ Annual Conference of the Agricultural Economics Society. Royal Agricultural College, Cirencester, UK.

Jang J., Olson F., 2010. The Role of Product Differentiation for Contract Choice in the Agro- Food Sector. European Review of Agricultural Economics, 37(2): 251-273.

Johanson J., Mattson L.G., 2015. International in Industrial System - A Network Approach. In: Forsgren M., Holm U., Johanson J. (eds.), Knowledge, Networks and Power. London: Palgrave Macmillan.

Johnson C.S., Foster K.A., 1994. Risk Preferences and Contracting in the US Hog Industry. Journal of $\mathrm{Ag}$ ricultural and Applied Economics, 26(2): 393-405.
Katchova A., Miranda M., 2004. Two-Step Econometric Estimation of Farm Characteristics Affecting Marketing Contract Decisions. American Journal of Agricultural Economics, 86(1): 88-102.

Key N., Runsten D., 1999. Contract farming, smallholders, and rural development in Latin America. World Development, 27(2): 381-401.

Key N., McBride W., 2003. Production Contracts and Productivity in the U.S. Hog Sector. American Journal of Agricultural Economics, 85(1): 121-133.

King R.P., Backus G.B.C., Gaag M.A., 2007. Incentive Systems for Food Quality Control with Repeated Deliveries: Salmonella Control in Pork Production. European Review of Agricultural Economics, 34: 81-104.

Kumar S., Chand P., Dabas J.P.S., Singh H., 2010. Characteristics and determinants of contract design of wheat seed farming in India: A basis of decision making. Indian journal of agricultural economics, 65(4): 621-637.

Lajili K., Barry P.J., Sonka S.T., Mahoney J.T., 1997. Farmers' Preferences for Crop Contracts. Journal of Agricultural and Resources Economics, 22(2): 264-280.

Macneil I.R., 1980. Power, contract, and the economic model. Journal of Economic Issues, 14(4): 909-923.

Malorgio G., Biondi B., Perito M.A., 2016. Strategic behaviour of Italian fruit and vegetables importers from South Mediterranean Countries faced with food safety standards. New Medit, 15(3): 29-36.

Menard C., 2008. A new institutional approach to organization. In: Menard C., Shirley M.M. (eds.), Handbook of New Institutional Economics. Berlin, Heidelberg: Springer.

Morgan R.M., Hunt S.D., 1994. The Commitment-Trust Theory of Relationship Marketing. Journal of Marketing, 58(3): 20-38.

Nait Mohand N., Hammoudi A., Radjef M.S., Hamza O., Perito M.A., 2017. How do food safety regulations influence market price? A theoretical analysis. British Food Journal, 119(8): 1687-1704.

Nguyen A.T., Dzator J., Nadolny A., 2015. Does contract farming improve productivity and income of farmers?: A review of theory and evidence. The Journal of Developing Areas, 49: 531-538.

Opoku - Mensah S., 2012. Logistic Analysis of Factors Motivating Smallholder Farmers to Engage in Contract Farming Arrangements with Processing Firms in Ghana. Journal of Biology, Agriculture and Healthcare, 2(11): 58-73.

Otsuka K., Nakano Y., Takahashi K., 2016. Contract farming in developed and developing countries. Annual Review of Resource Economics, 8: 353-376. 
Parcell J.L., Langemeier M.R., 1997. Feeder-Pig Producers and Finishers: Who Should Contract? Canadian Journal of Agricultural Economics, 45: 317-327.

Perito M.A., De Rosa M., Bartoli L., Chiodo E., Martino G., 2017. Heterogeneous Organizational Arrangements in Agrifood Chains: A Governance Value Analysis Perspective on the Sheep and Goat Meat Sector of Italy. Agriculture, 7(6): 47.

Reardon T., Barret C., Berdegue J., Swinnen J., 2009. Agrifood industry transformation and small farmers in developing countries. World Development, 37(11): 1717-1727.

Reardon T., Gulati A., 2008. The supermarket revolution in developing countries. Policies for "competitiveness with inclusiveness". Policy Brief 2. Washington, DC: International Food Policy Research Institute.

Roussy C., Ridier A., Chaib K., Boyet M., 2017. Marketing Contracts and Risk Management for Cereal Producers. Paper presented at the XV EAAE Congress "Towards Sustainable Agri-food System: Balancing between Markets and Society", Parma, Italy.

Stoker G., 1998. Governance as theory: five propositions. International Social Science Journal, 50(155): 17-28.

Swain B.B., 2012. Determinants of Farmers' Participation in Contract Farming: The Cases of Gherkin and Paddy Seed in Andhra Pradesh, India. Millennial Asia, 3(2): 169-185.
Ton G., Vellema W., Desiere S., Weituschat S., D'Haese M., 2018. Contract farming for improving smallholder incomes: What can we learn from effectiveness studies? World Development, 104: 46-64.

Vavra P., 2009. Role, Usage and Motivation for Contracting in Agriculture. OECD Food, Agriculture and Fisheries Working Papers, No. 16. Paris: OECD Publishing, doi: 10.1787/225036745705.

Viaggi D., Zanni G., 2012. The Role of Production Contracts in the Coordination of Agri-Food Chain: Evidence and Future Issues for the Durum Wheat Chain in Italy. In: Rezitis A.N. (ed.), Research Topics in Agricultural and Applied Economics, vol. 3. Sharja: Bentham Science Publishers, pp. 12-22.

Wilson W.W., Dahl B.L., 2011. Garin Contracting Strategies: the Case of Durum Wheat. Agribusiness, 27(3): 344-359.

Wilson W.W., Maxwell B.J., Dahl B.L., 2004. Incentive contracts to meet functional characteristics in wheat purchasing. Agribusiness \& Applied Economics, Report No. 545.

Worley T., McCluskey J.J., 2000. Production Contracts as a Means of Vertical Coordination with Application to the Wheat Industry. Journal of Food Distribution Research, 31(1): 215-224.

XhoXhi J., Keco R., Skreli E., Imami D., Musabelliu B., 2019. The Role of Intermediaries' Power on Contracting Decision Between Farmers and Intermediaries. New Medit, 18(3): 3-16. 